\title{
Educational environment forming on the basis of the human capital development
}

\author{
Alexander Karpov ${ }^{1,}{ }^{*}$, Alexander Kharin $^{2}$, and Olga Kharina ${ }^{3}$ \\ ${ }^{1}$ Moscow Technological Institute, 199334, Moscow, Russia \\ ${ }^{2}$ MSTU "STANKIN", education department, Moscow, Russia \\ ${ }^{3}$ RSUITB, education department, Moscow, Russia
}

\begin{abstract}
In the article the role of human capital usage in innovative economy growth, the role of modern higher education in this process are analyzed together with the approaches to the educational environment forming on the basis of the human capital development.
\end{abstract}

\section{Introduction}

For a long time human capital has been viewed only as a social, i.e. non-economic from the perspective of economics, development factor, as it was believed that investment into upbringing and education cannot be productive. The second half of the 20th century saw profound changes in the attitude towards human capital and education. According to the World Bank, only 15$16 \%$ of economic growth is conditioned by physical capital, about $20 \%$ - by natural capital, and $64-65 \%$ is driven by human capital [1].

It is the high level and quality of human capital of a country with a catching-up economy that ensures steady growth of its GDP and a rise in living standards. Thus, human capital is the keynote of potential steady economic growth in developing countries.

The level of development and use of modern technologies and introduction of innovations in an information society is defined by the level of intellectualization of the population, its capability to produce, master and put into practice knowledge, technologies, forms and methods of labor organization, rather than by the development of material resources of the country. The level of intellectualization of society is closely connected with the level of education and professional qualification of labor, consequently, with human capital as well.

\section{Analysis and discussion}

The notion of value of information in modern society is important like never before. It underlies management decisions affecting the future of a company, development of an industry or even the economy of a country in general. Being a direct source of extensive reproduction of qualified labor, modern universities strategically influence the transformation of human capital, as well as set the frame for the potential for its intensive development through the use of innovations. Today, due to increased significance of human capital in innovation processes, specialists with higher education are required to have a higher level of competence, and universities are required to provide a higher quality of their preparation.

In modern society all educational processes are closely intertwined. Obtaining an education constitutes a fundamental part of acquiring knowledge, and combined with practice, research and socialization promotes human capital accumulation. If we assume that social development is a relatively long period of achieving human capacity lasting for 5-10 years, than the primary elements are a constant information flow, expansion of learning, increase of problem-solving capacity, and development of creative skills.

Under modern conditions educational activity becomes increasingly important for the society, since knowledge is developing faster and tends to become obsolete faster than before. For that reason the role of universities in human capital accumulation of a single person and the society as a whole becomes increasingly important, as knowledge becomes a source of progress and successful economic and innovative development of a state.

In recent years, due to intensive development of innovative activity in the university sector, Russian universities assumed the part of immediate producers of science-intensive high-demand market products created based on their existing intellectual property assets, as well as the part of intermediaries between industries and researchers, providing for commercialization of inventions. However, under modern conditions universities should be focusing less on direct inclusion into industrial activity, and more on spurring interaction for introduction and market launch of R\&D projects and acting as an intermediary between science and real

* Corresponding author: a karpov@,mti.edu.ru 
economy. The basis for that may firstly be provided by a high level of research, and secondly by integration of science and education.

Most researchers agree on the main reasons of changes in the role played by universities, related to the transition towards information society and innovationdriven economy:

- an increasingly important role of knowledge and information in social and economic development;

- the need for highly qualified employees, mainly for high-technology production, which generates mass demand for higher education;

- increasingly stringent requirements to universities with regard to meeting social needs, specifically, governmental and industrial needs;

- globalization of the international economy.

That forced universities to reconsider their objectives and tasks, to explore new areas of activity previously unusual for this kind of institutions, to recognize the need to reinvent their role in the new emerging knowledge-based society. The role of universities in human capital formation under innovation-driven economy is increasingly important.

\section{Results}

Having analyzed the existing theoretical and practical groundwork in human capital and the role of universities in innovation-driven economy, one can come to the following conclusions:
1. Knowledge, skills and experience accumulated by a person are the main engine of progress and a major factor of economic development of a country. Human capital conditions the potential for transition of an economy towards the path of innovation-driven development and the rise of living standards.

2. Education, research, practical activity and social contacts constitute the basis for acquiring, updating and accumulating human capital. A university combines all these educational processes, provides skills for the organization of self-education and accumulation of human capital in the future.

3. Human capital is developed in the process of economic and scientific activity of individuals and affects the development of both the economy and science, which demonstrates mutual influence between the sectors of education, science and the economy.

4. The role of universities in the modern society is not confined to mere execution of the educational function; they become a platform for innovative development, a basis for research, and active participants of the innovation-driven economy.

\section{Reference}

1. World Development Report 2015: Mind, Society, and Behavior.

https://openknowledge.worldbank.org/handle/10986 $/ 20597$ 